\title{
Spotlight on early childhood education. A newspaper coverage analysis of universal preschool debate in Argentina
}

\author{
Carolina Snaider ${ }^{*}$ (D)
}

*Correspondence: cs3495@tc.columbia.edu Teachers College, Columbia University, New York, USA

\begin{abstract}
Throughout the past decade, the Argentinean government has lowered the starting age of compulsory education and early childhood education enrollment has been growing steadily. However, ECE services have evolved in a fragmented manner, leading to an unequal and inequitable scenario: while private education supports the largest part of the growth, children from low-income families are less likely to attend preschool and more likely to receive low-quality service. Through a newspaper coverage analysis, I explore how these problems are addressed in the public debate on universal preschool. Results show that the voices of policy-makers and "experts" are prominent while teachers' and parents' views are ignored; I found a widespread consensus for universal preschool and a scarcity of arguments against. I suggest the need to draw on research findings in ECE more critically and posit that the need to ensure high quality preschool for all children should be central in the debate.
\end{abstract}

Keywords: Argentina, Early childhood education (ECE), Education policy, Universal Pre-K

\section{Background}

Educating infants and toddlers has historically been a private enterprise: home was the "right" place for children, and mothers assumed to be the primarily responsive adult (Bloch 1987; Fuller 2007). "Only under the most limited of conditions-when families could not help themselves-was government called upon to intervene" (Kagan 2009, p. 4). But this approach to early childhood (EC) has notably shifted: over the past five decades, EC has progressively turned from a primarily private-family responsibility into a public-state concern.

Since the mid 60s, when women left their homes to enter the labor market, the number of young children attending some form of out-of-home early childhood education (ECE) has grown steadily. In addition, by the end of the twentieth century, studies in the field of Child Psychology and Pedagogy altered our understanding of childhood, centering attention on children's developmental needs, the learning potential entrenched in the first years of life, and the negative consequences that improper stimulation during EC might cause (Diker 2001; New 2016). Advancements in neuroscience also reinforced our understanding of EC as a crucial sensitive period and concluded "early environments

(c) The Author(s) 2018. This article is distributed under the terms of the Creative Commons Attribution 4.0 International License (http://creativecommons.org/licenses/by/4.0/), which permits unrestricted use, distribution, and reproduction in any medium, provided you give appropriate credit to the original author(s) and the source, provide a link to the Creative Commons license, and indicate if changes were made. 
and experiences have an exceptionally strong influence on brain architecture" (National Scientific Council on the Developing Child 2007, p. 2). Furthermore, economic analyses show that investment in the early years results in higher returns than making investments later in life (Heckman 2006; Neuman and Devercelli 2013). In sum, a growing body of studies from distinctive disciplines strongly agrees that EC is a crucial developmental stage in which lifelong cognitive, socio-emotional, and physical development are rooted (Shonkoff and Phillips 2000; Couse and Recchia 2016). As expected, ECE is no longer understood as a private concern affecting working parents, but as a public issue, beneficial for children's development and the society as a whole. Far from being, as in its origin, a private enterprise, ECE gained terrain in the international public agenda and, in western democracies, it became an arena of significant policy innovation (Brennan 2007; Farrell et al. 2016).

\section{ECE in Argentina}

Argentina-the context for which I focus the study-is notably aligned with the international panorama I described above: ECE has progressively turned from a private into a public matter, it became a major focus in the political agenda and enrollment has been growing steadily since the beginning of the twenty-first century.

Worth clarifying, ECE encompasses the life period from birth through age 8, and embraces a broad array of services offered to children and their families such as healthcare, nutrition, education, and welfare, to name a few. Altogether, these comprehensive services influence children's language, physical, intellectual, and social development (Naeyc 2009). For analytical purposes, as my focus is this paper is on the universal preschool debate in Argentina, I use the term ECE to refer only to educational services offered to children previous to primary education.

ECE in Argentina is called Initial level and constitutes the first levels of the educational system. It involves education from birth to age 5 , being 4 the starting age of compulsory education. Yet, this has not always been the case. Not until the end of the twentieth century, with advancements in the field of child development showing that ECE could enrich children's development, learning and socialization, did ECE became a state concern within the educational sphere (Diker 2001; López 2012; Malajovich 2010; Terigi 2012). Indeed, ECE was for the first time formally included in the educational system in 1993, when the Federal Education Act No 24.195 established kindergarten $(5 \text { years })^{1}$ as the starting age of compulsory education.

In 2006, the new National Education Act No 26.206 replaced the Federal Education Act No 24.195. This confirmed kindergarten as the mandatory starting age as well as added the goal of universal preschool for children aged 4, requiring the state to guarantee the educational supply. In December of 2014, Congress passed Law No 27.045, lowering both the starting age of compulsory education from 5 to 4 years, and the goal of universal preschool from children aged 4 to children aged 3. Currently, Congress is

\footnotetext{
${ }^{1}$ In Argentina, the Nivel Inicial [Initial Level] is divided into two sub-levels (a) Jardin Maternal [Maternal Garden] which includes 45-days to 2-years-old classrooms, and (b) Jardin de Infantes [Kindergarten], which includes 3-years-old to 5 -years-old classrooms. For alignment with the international jargon, I use the term kindergarten to refer to 5 years and preschool to refer to all ECE services from birth to 4 years.
} 


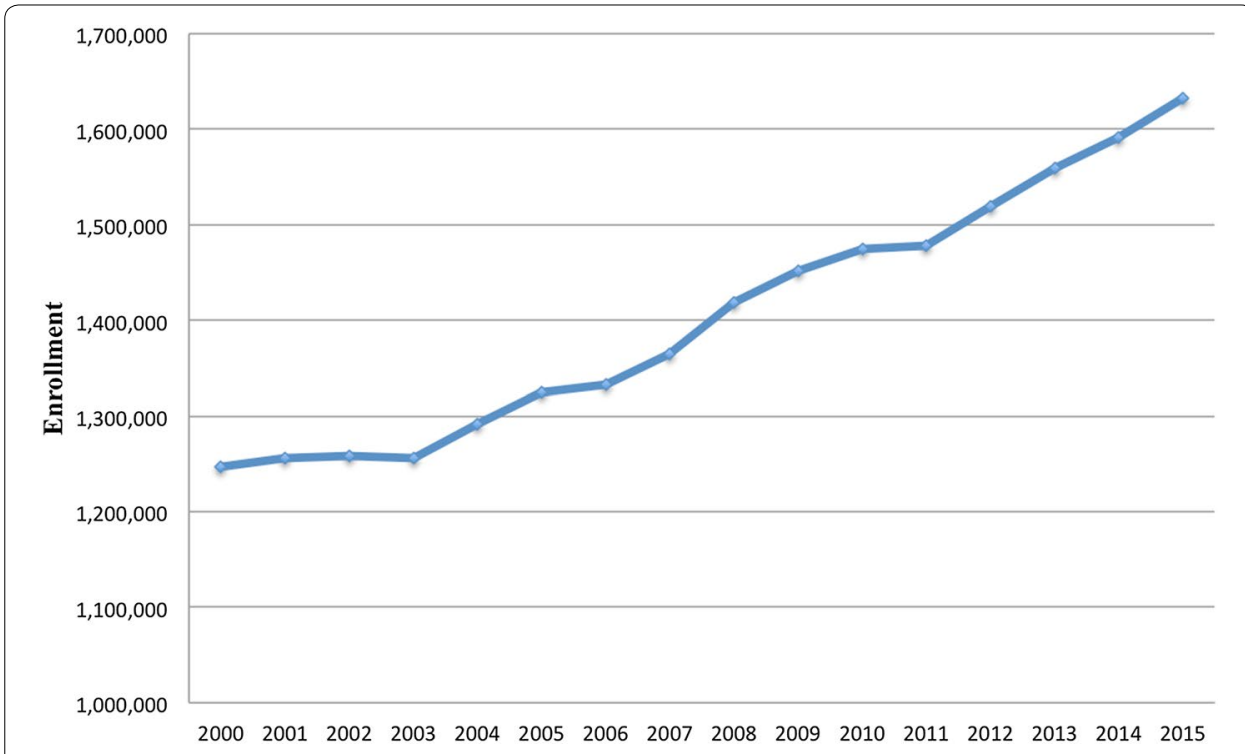

Fig. 1 Argentina preschool (3 and 4 years) and kindergarten (5 years) enrollment, 2000-2015. Own elaboration based on data published by the National Agency of Information and Statistics in Education, Argentina

debating the authorization of a new law that aims to lower the starting age of compulsory education even further, to 3 years.

As Fig. 1 shows, ECE enrollment for children aged 3-5 in Argentina has been growing steadily since the beginning of the twenty-first century. In 2000, 1,246,597 children attended preschool or kindergarten, while 1,632,365 did so by 2015 . This equals to an increase of roughly 386,000 , or a $31 \%$ total enrollment growth in the last 15 years.

Schooling rates are even more informative: the schooling rate for kindergarten (5 years) was 78.8\% in 2001 and climbed to $91.4 \%$ in 2010 (National Institute of Statistics and Census 2012). On the other hand, the schooling rate for 4-year-olds in 2001 was $48.2 \%$ and increased to $69.8 \%$ in 2010. For 3-year-olds, it increased from $29.9 \%$ in 2001 to $40.4 \%$ in 2010 (Argentinean National Institute of Statistics and Census 2012).

Furthermore-as Table 1 indicates-the private sector has been supporting a larger part of ECE enrollment growth. Between 2000 and 2015, private education enrollment increased about 47\%-almost twice the growth of the public sector, which was about $25 \%$.

Similarly, the private school share of total enrollment grew almost 3\% points throughout the past 15 years. By 2015, of all children aged 3, 4, and 5 years enrolled in ECE, roughly 42, 31, and $28 \%$ attended private services, respectively (National Agency of Information and Statistics in Education 2015).

To provide a broader conceptual frame, it is important to explain that while public preschools and kindergartens are publicly financed and the service for the families is free, families finance private school by paying monthly tuitions. Both private and public preschools and kindergarten must follow the official curriculum, teachers should be certified, and structural variables such as infrastructure, group sizes and, teacher per students ratios, are highly regulated. Fair to mention, private schools can also receive state subsidies to partially cover teachers' salaries and are granted greater autonomy in some 
Table 1 Argentina private and public preschool (3-4 years) and kindergarten (5 years) enrollment, 2000-2015

\begin{tabular}{lllll}
\hline & Private & Public & Total & Private/total (\%) \\
\hline 2000 & 351,675 & 894,922 & $1,246,597$ & 28.81 \\
2001 & 354,820 & 900,870 & $1,255,690$ & 28.93 \\
2002 & 348,426 & 909,994 & $1,258,420$ & 28.47 \\
2003 & 352,679 & 903,332 & $1,256,011$ & 29.05 \\
2004 & 378,138 & 913,934 & $1,292,072$ & 30.34 \\
2005 & 401,422 & 923,107 & $1,324,529$ & 31.38 \\
2006 & 409,356 & 923,166 & $1,332,522$ & 31.83 \\
2007 & 422,944 & 941,965 & $1,364,909$ & 32.28 \\
2008 & 451,467 & 967,291 & $1,418,758$ & 33.06 \\
2009 & 471,074 & 981,199 & $1,452,273$ & 33.62 \\
2010 & 474,477 & $1,000,388$ & $1,474,865$ & 33.33 \\
2011 & 473,182 & $1,005,437$ & $1,478,619$ & 33.24 \\
2012 & 486,120 & $1,032,986$ & $1,519,106$ & 33.35 \\
2013 & 493,010 & $1,066,428$ & $1,559,438$ & 33.48 \\
2014 & 504,470 & $1,086,883$ & $1,591,353$ & 33.58 \\
2015 & 515,598 & $1,116,767$ & $1,632,365$ & 33.51 \\
$\Delta \% 2000-2015$ & $46.61 \%$ & $24,79 \%$ & $30.95 \%$ & $3.38 \%$ \\
\hline
\end{tabular}

Own elaboration based on data published by the National Agency of Information and Statistics in Education, Argentina

aspects such as staffing procedures and curricular innovations (Morduchowicz 1999; Narodowski and Andrada 2001).

As other scholars have analyzed, by the second half of the twentieth century, the Argentinean State faced financial constraints to support universal public education for all children. Since then, private education in the country has showed a steady growth in absolute and relative terms (Narodowski and Moschetti 2015; Narodowski et al. 2016; Narodowski and Snaider 2015; Vior and Rodríguez 2012). Given this context, it is not surprising that the expansion of preschool and kindergarten has been possible, in large part, because many families afford month-by-month the cost of private school tuitions.

Indeed, besides kindergarten that has been almost universalized (i.e., in 2015 the schooling rate was 96.3\%) (Unesco 2016), children's chances of attending out-of-home ECE is associated with their socio-economic background. Figure 2 clearly illustrates what Bassok et al. called "the socioeconomic gap in early childhood experiences" (2016, p. 1): as children's socioeconomic levels increase, attendance in ECE does, as well.

In 2012 (the last year these data were available), only $20.7 \%$ of children in the lowest socio-economic quintile attended ECE. For those in the highest quintile, attendance rate was $52.1 \%$.

In summary, ECE enrollment in Argentina has been growing steadily since the beginning of the twenty-first century. However, private education supports a larger part of the increase, leading to a highly unequal landscape. Children from low-income families, who cannot afford the cost of private education, have fewer chances to attend preschool.

\section{The ECE foundational fracture}

In addition to the "privatization phenomenon" in Argentina, the ECE landscape is further complex and problematic as services are not only restricted to public or private 


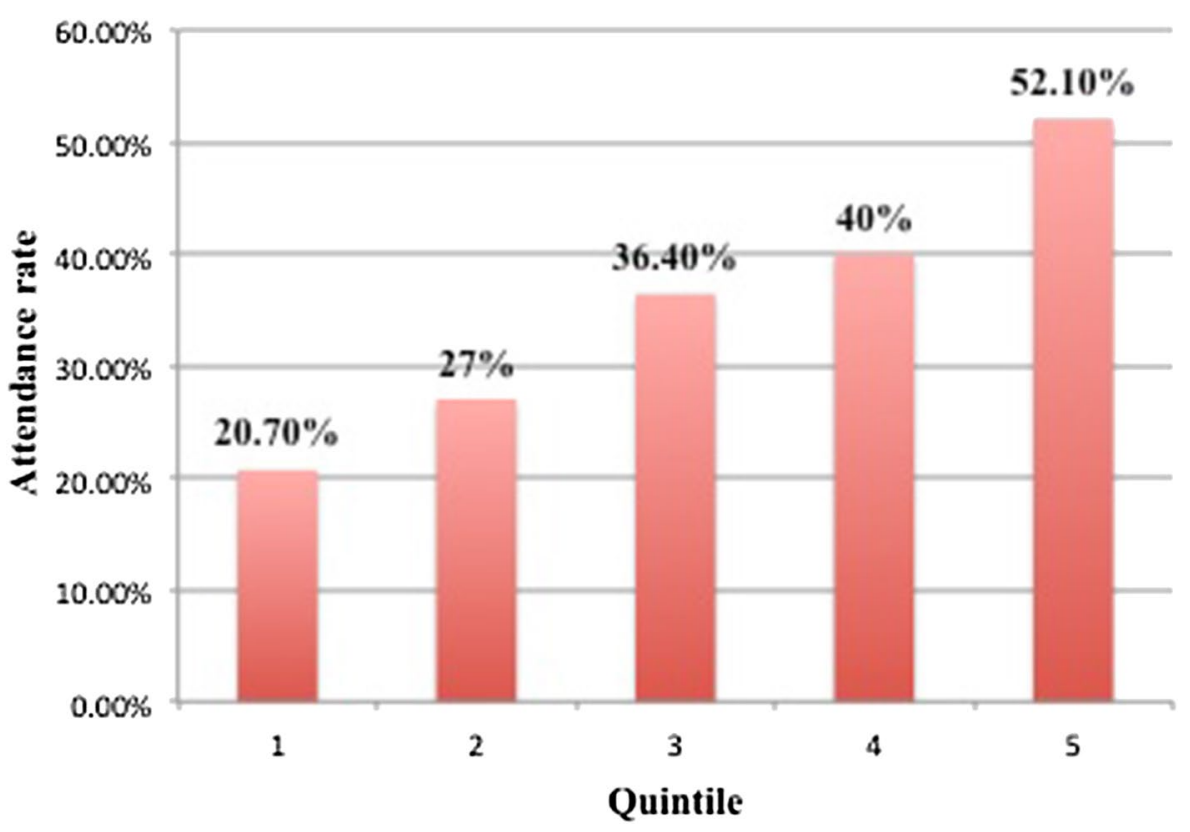

Fig. 2 Argentina attendance to preschool (birth to 4 years) by socioeconomic quintile, 2012 (Adapted from "Encuesta Sobre Condiciones de Vida De Niñez y Adolescencia" by Gerosa and Thourte n/d, Ministerio de Desarrollo Social de la Nación \& UNICEF)

schools. As I mentioned above, not until 1993 with the passage of the Federal Education Act No 24.195 was ECE incorporated to the educational system. It turns out that due to the State's original focus on ensuring universal primary education, but mostly grounded in the socio-historical belief that mothers were the primary and foremost caregiver of young children, ECE services in Argentina originated and expanded well beyond the scope of the educational authorities (Malajovich 2010; Redondo 2012). Therefore, they have evolved in a very chaotic, incoherent, and fragmented fashion (Ponce 2006; Redondo 2012; UNICEF and UNSAM 2011; Itzcovich 2010). Though beyond the scope of this article, it is worth noting that such contested origins and fragmented evolution are incredibly analogous with ECE history in other countries, such as the case of the United States (Cahan 1989).

As I will next develop, Argentina has still not overcome such foundational fracture. A broad diverse array of institutions coexist, differing in terms of their main goals, funding streams, regulations, and the governmental sector to which they respond. This hodgepodge of ECE services is not innocuous, but rather totes severe inequities and inequalities that, day-by-day, affect the Argentinean youngest generations.

Until the end of the twentieth century, state intervention in ECE restricted to cases in which families were deemed as incapable of guaranteeing child wellbeing (Malajovich 2010; Ponce 2006). "To prevent the negative consequences of family dysfunctions on children's development", the Argentinean government developed a system of custodial care, creating daycares within the welfare system (Malajovich 2010; Martin et al. 1977). Renamed in 2007 as Centers for Child Development (CeDIs, as its Spanish acronym) (National Law No 26.233), these centers are still providing free, full-day ECE services to children from low-income families. The adults in charge of the children are not required 
to have any credential nor professional training (Repetto et al. 2012). Though the CeDIs have a declared pedagogical goal, studies have found that the nutritional component (i.e., providing breakfast, lunch and afternoon snack) is the foremost service provided. The Ministries of Social Development fund and manage the CeDIs, which lack pedagogical supervision (Repetto et al. 2012; Snaider 2014).

Similarly, in the middle 60s when women entered the labor force, state response was absent. Hence, for-profit ECE services expanded within the private sector with the major goal of taking care of children while their mothers were at work. Families had to afford all the cost of the services by paying monthly fees. Broadly identified as non-formal private centers, these institutions operated beyond the scope of educational authorities, following only fiscal and sanitary and hygienic norms (Arakaki et al. 1986; Martin et al. 1977). Strikingly, this is still the case for many jurisdictions, where for-profit, non-formal private centers are legally framed as a business; they are not required to hire qualified teachers; neither are they mandated to implement a curriculum, nor are they supervised by education authorities (Burgos and Silva 2013).

Fair to acknowledge, since the early 2000s several jurisdictions have made some progress in this regard: governments have passed laws that oblige these private centers to get an authorization from educational authorities to operate. Also, the updated legal frameworks involve regulations beyond basic safe and sanitary standards. However, in comparison to public and private preschools and kindergartens, these regulations are notably less stringent in terms of infrastructure requirements, teacher qualifications, group sizes, and adult per children ratios, among others (Snaider 2014).

The diversity in ECE arrangements goes even further: during the late 1980s and throughout the 1990s, Argentina implemented a set of neoliberal economic policies (e.g., privatization of public services such as electricity, telephone lines and postal service; closure of national shipping line and coal mines) that severely increased unemployment and led many families to poverty (Narodowski and Snaider 2015). Thus, local initiatives within the so-called third sector aroused to address the basic needs of young children that were being neglected by the state. Non Governmental Organizations (NGOs) founded Community Centers, where volunteer mothers took care of young children, mostly providing nutritional services and custodial care while their parents were out looking for a job (Kantor and Kaufmann 2008; Sverdlick et al. 2007). Currently, the state lacks quantitative data regarding the Community Centers (Kantor and Kaufmann 2008; Redondo 2012). Qualitative studies, however, have found that most of them are located in disadvantaged neighborhoods-where public and private preschools are scarce or inexistent. They have precarious infrastructures and a lack of qualified staff (Kantor and Kaufmann 2008; UNICEF and UNSAM 2011).

Finally, many Community Centers have "evolved" into Centers for First Infancy (CPIs, as its Spanish acronym). During the past decade, the national government has been establishing agreements with the NGOs to transform their Community Centers into CPIs. Basically, the government provides the funding according to the number of children served and the NGO takes responsibility for the provision of the service. In 2016, the national government launched the National Plan for Early Childhood committing to create 4000 new CPIs across the country (Decree No 574). In fact, outsourcing the provision of the ECE service by subsidizing third parties as service providers is a model that 
has been widely adopted by Latin American countries during the last decades (Araujo et al. 2013). CPIs provide free, full-day services to socio-economically disadvantaged children. Again, regulations are less stringent than the requirements for the formal public and private preschools and kindergartens: The CPIs do not necessarily operate within the framework of a pedagogical curriculum, children per teacher ratios and teacher turnover rates are remarkably high. As they respond to the Ministry of Social Development, they lack supervision and technical assistance from educational authorities (Flaso and Cippec n/d; Narodowski and Snaider 2017; Snaider 2014, 2016).

Official enrollment data for both, Community Centers and CPIs have not been published. Just to illustrate, unofficial sources have estimated that in the Province of Buenos Aires-whose population represents 30\% of the total country (http://www.indec. gob.ar)-Community Centers enrollment was 70,000 children in 2016 ("Duras críticas" 2016).

To summarize, Argentinean young children attend public and private preschools and kindergartens; non-formal private centers, CeDIs, Community Centers and, CPIs. I have provided a brief typology of the major ECE arrangements in Argentina and showed that, rooted in contested, socio-historic cultural ideologies regarding who holds responsibility for child-well being and what are the purposes of ECE (e.g., enrich children's development and learning, compensate "family's dysfunctions," replace parents while they are at work) ECE services for young children have evolved significantly fragmented.

This foundational fragmentation has lead to a highly segregated, unequal and inequitable ECE landscape. On the one hand, private education supports a larger part of the enrollment and children from high- and middle-income families are more likely to attend formal preschools. These institutions are part of the educational system and, compared to all other ECE settings, are the ones of higher quality, in terms of infrastructure, teacher qualifications, group sizes, and curriculum, among other regulations. On the other hand, children from low-income families have less chances of attending ECE. In the case they do attend, they have higher chances of receiving a relative low-quality service at CPIs, CeDIs and Community Centers which have less resources, qualified personal and respond to less stringent regulations.

My goal in this paper is to analyze how these problems of the ECE landscape in Argentina are addressed in the public debate on universal and compulsory preschool. For this purpose, I will conduct a newspaper coverage analysis to answer: what are the major topics covered regarding ECE? Whose voices are being heard? What are the arguments presented for and against universal and mandatory ECE in Argentina? The roadmap is as follows: I will first describe the methods I used to collect and analyze the data. Second, I will present the main findings, organizing them in terms of (a) what the news says about EC (i.e., main topics covered), (b) who says it (i.e., main social actors included in the debate) and, (d) why do they say what they say (i.e., arguments for and against expanding out-of-home ECE). Finally, in the discussion I will summarize the major trends detected throughout the newspaper coverage analysis, reflect on the limitations of the current public debate, and point out the severe consequences that those limitations entail for the Argentinean youngest generation. 


\section{Methods}

To examine the ongoing public debate in Argentina around universal and mandatory preschool I conducted a media analysis (Matheson 2005). Media are often referred to as "agenda setters" as they determine which issues are newsworthy and increase exposure for the issues they deem important (Sigillo and Sicafuse 2015; Soroka et al. 2012). Also, the way media frame the news, "filter and translate scientific information to the public" (Epstein 1996 as cited in Pyzmony-Levy 2016, p. 3) influences not only what social problems are considered relevant, but also how individuals perceive these issues (Soroka et al. 2012). Therefore, considering the fragmentation, inequalities and inequities in the ECE Argentinean landscape, I conducted a media analysis to explore how these controversial issues are being framed; explore what-and what is not-being said, "who are identified as key stakeholders" (Hodgertts and Chamberlain 2014, p. 38) and, who are "inaudible or silenced" (Juffermans and Van-Der Aa 2013, p. 114).

I collected the news from a purposive sample of four Argentinean newspapers: (a) Clarin, (b) La Nación, (c) Diario Popular, and (d) Página 12. I selected the first three (i.e., Clarín, La Nación and, Diario Popular) as being the top Argentinean newspapers: According to official data from the System of Cultural Information of Argentina, in 2014 Clarín had a net circulation of 231,727 newspapers per day, followed by La Nación with 154,879 and, in third place was Diario Popular with a daily net circulation of 79,943 newspapers. In addition to this quantitative criterion for selecting the data sources, I was interested in capturing divergent political editorial positionalities across the newspapers. Thus, as Clarín and La Nación are newspapers that culturally identify with a conservative political orientation and Diario Popular is linked with sensationalist press, I additionally included Página 12 in the sample, as being the Argentinean newspaper that identifies with the left wing.

I searched for the data through each newspaper's online search engine, using the keywords: Primera infancia [Early Childhood], jardin de infantes [Kindergarten], jardin maternal [Preschool], ley No 27.045 [Law No 27.045], sala de 4 [4 years-old classroom] and, sala de 3 [3-year-old classrooms]. I limited the search to the period from January 2014-as being the year that Law No 27.045 was passed-until December 2016, as the new project to lower the starting age of compulsory education to 3 years was already under consideration.

To analyze the data, I started by reading the headlines and the introductory paragraphs of the articles. In this preliminary step, I conducted an inductive data analysis, identifying the recurring themes across the articles and grouping them accordingly (e.g., paternal leave, technology and child development, early schooling). Then, I performed a more in-depth reading of the 43 news reports that addressed, at a national level ${ }^{2}$, the topic of early schooling. For each article, I conducted a first round of coding, according to three main codes: (a) arguments for expanding preschool, (b) arguments against expanding preschool and (c) spokesmen (i.e., whose voices were cited in the articles).

\footnotetext{
${ }^{2}$ Argentina has a federal political administration. The governments of Argentina's 24 jurisdictions administer their own educational systems, within the frame of national guidelines. For reasons of feasibility, in this work I analyzed the articles addressing early schooling issues at a national level and discarded those that addressed issues at the provincial level.
} 
Afterwards, I conducted a second round of coding, analyzing the arguments for and against early schooling in Argentina. For the arguments supporting universal preschool I used 4 theoretical codes, drawn from the major arguments for ECE that are found in the literature (Siraj-Blatchford and Woodhead 2009): (a) Children's right, (b) social justice, (c) human development, and (d) cost-efficiency. Though I remained observant of "disconfirming" data, I did not encounter arguments for ECE that required creating an additional code. In contrast, I did create codes to make-sense of the arguments against ECE: in the process of identifying recurring arguments against universal ECE, I developed three codes: (a) family choice, to group quotes referring to the parent's right to decide how to educate their children, (b) socio-emotional development, to group claims of ECE affecting negatively children's emotions and behaviors, and (c) high-quality warnings, clustering the statements stressing the need of high-quality services. I will further develop on the content of each one of these codes in the following results section.

Finally, it is noteworthy that I conducted the most feasible systematic and comprehensive search. Yet, due to limitations of the newspapers online search engines (e.g., most of them lack search filters such as date of publication) I might have omitted some eligible news. Nevertheless, based on the theoretical saturation I arrived at while analyzing the news, I consider that it is highly improbable that any newspaper article overlooked might radically modify my findings and conclusions.

\section{Results}

\section{What is said? Major topics in ECE}

The process of selecting the news allowed me to distinguish six major ECE themes recurrently covered by the media: (a) technology and child development, (b) paternal leave, (c) child nutrition, (d) child poverty, (e) child abuse and maltreatment and, (f) the topic on which I deepened the analysis, universal and mandatory preschool. Although in this article I do not delve into the first five issues, I consider it worthwhile to mention them as a relevant finding of my data search that might inform further research studies.

Specifically, for the topic of early schooling, most the articles (i.e., 15 articles) discussed the Law No 27.045 that established age 4 as the mandatory starting age for education; eight articles focused on the current government initiative of lowering it to 3 years, and nine on the expansion of the "alternative" centers (i.e., Community Centers, CeDIs and CPIs). The remaining 11 news reports discussed more broadly, i.e., not attached to any policy issue, the pros and cons of out-of-home ECE at an early age.

\section{Who says it? Major voices in ECE}

Regarding whose voices are most prominent in ECE news, I found that the views of policy-makers came first. This group includes government officials such as Presidents, Mayors, Ministers of Education and Ministers of Social Development, as well as Congressmen. Their statements regarding ECE appeared in 29 of the 43 news reports I reviewed.

In second place, I found the voices of those considered "experts" in the field, contributing their perspectives to assess the ECE government initiatives. The opinions of psychologists, neuroscientists, doctors, and scholars in the field of education play a major role in this sense. I encountered their views in 16 news reports from Diario Clarín and La 
Nación. In contrast, for Diario Popular and Página 12, I did not find any direct testimony from scholars or other professionals in the field of ECE. In these editorials, the "experts" voices were not included at first hand, but embedded in the policy-makers' voices, as they cited research studies to support their claims.

Remarkably, I did not find any EC teachers' view within the subgroup of "experts." No EC educator's voice emerged across the 43 news reports. Likewise, the voices of families were almost null. Parents' perspectives appeared in only one article.

\section{Why do they say it? Major arguments in ECE}

Across the news reports policy-makers and "experts" in the field of ECE make their cases for and against ECE. The majority, indeed, were arguments for universal and mandatory ECE public policies. On the other hand, arguments opposing early schooling were remarkably scarce. Most of them were not direct rejections to universal and mandatory preschool policies but rather concerns regarding high-quality issues.

\section{Arguments for early schooling}

Following, I present the cases in favor of universal and mandatory preschool according to four major lines of arguments that appeared in the ECE literature (Siraj-Blatchford and Woodhead 2009): (a) the children's rights argument, (b) the social justice argument, (c) the human development argument, and (d) the economic argument. As the reader might notice, sometimes boundaries across these foci blur, but for analytical purposes I analyze them independently.

\section{The children's rights argument}

By the end of the twentieth century, the old "tutelary paradigm" in which children were considered passive and incomplete beings, gradually turned to the "children's rights paradigm" in which children are considered complete subjects and meaningful social actors (López 2012). The Convention on the Rights of the Child passed in 1989 was a milestone in this shift. Argentina approved the Convention through Law No 23.849 in 1990 and included it in its Constitution in 1994. In the same vein, in 2005 the Children's Patronage Act No 10,903-framed in the old tutelary paradigm and in force since 1919-was replaced by the Children and Adolescents' Right Act No 26,061 that, as its name indicates, is aligned with the children's rights paradigm. Within the children's rights framework, ECE is their right, not an intervention needed to compensate for early deficits or a cost-effective investment to ensure future goals (Woodhead as cited in Siraj-Blatchford and Woodhead 2009). This approach emphasizes "the right of children to a happy and healthy childhood, not just because this will lead to better outcomes for them and their neighbors, but because there are certain experiences children intrinsically ought to have" (Waldfogel 2006, p. 6).

Across the 43 newspaper reports, I identified eight that included statements that apply to the children's rights case. For instance, an expert from UNICEF claimed, "it is important to invest in ECE for reasons of human rights"3 ("Según Unicef” 2016, para. 1). The

\footnotetext{
${ }^{3}$ I translated from Spanish all the newspapers quotations.
} 
same expert authored an article titled: "Rights since infancy [emphasis added]" (Bauer 2016). Regarding Law No 27.045 that lowered the mandatory starting age from 5 to 4 years, a deputy representing the then official government claimed: "It is an achievement of our democracy to include the youngest children in the educational system [emphasis added]" (Leverberg as cited in "El Congreso" 2014, para. 4). Also in support to Law No 27.045 the then President Cristina Fernández de Kirchner argued: “There are not democratic societies without education" (Kirchner as cited in Dillon 2014, para. 3) and the Ministry of Education stated that the law "guarantees for citizens a right, and rights are to be fulfilled" (Sileoni as cited in "El Gobierno" 2014, para. 3). In November of 2016, when the Chamber of Deputies approved the ongoing project to lower the mandatory starting age from 4 to 3, a deputy declared: "ECE is a children's right" (Riccardo as cited in "Diputados aprobó" 2016, para. 6).

In sum, Argentina legislation is framed within the children's rights perspective and across the news reports I found some references attached to the children's rights arguments. Although not abundant, it is worth noting that these references appeared across the four newspapers and in the voice of policy-makers with contrary political orientations. To clarify: Law No 27.045 was passed under the Fernández de Kirchner administration, a government linked to the left wing. The new law project, that aims to lower the mandatory starting age to 3 years, is an initiative from the Macri administration, the successor government that assumed in December of 2015 and, in contrast, is attached to a more conservative brand. I acknowledge this right-left classification I have just made for the two divergent administrations is notably more complex and controversial, but for the purposes of this study this simple depiction is rather sufficient: Both, politicians with a progressive discourse and politicians with a conservative discourse refer to ECE as a children's right when supporting universal and mandatory ECE.

\section{The social justice argument}

The social justice argument stresses the need to ensure every child equal opportunities. The effects of poverty on child development and academic performance are already well known (Brooks-Gunn and Duncan 1997). Evaluations from high-quality ECE programs (e.g., Perry Preschool in Michigan, 1960 and the Carolina Abecedarian in North Carolina, 1972) found in their participants better academic performance, higher employment rates, and less criminal activity, among others short- and long-term positive outcomes (Currie 2006; Johnson and Brooks-Gunn 2012; Schweinhart et al. 2005). Hence, drawing on the assumption that "high quality early care and education programs can indeed make a difference in the life course of disadvantaged children" (Johnson and BrooksGunn 2012, p. 362), the social-justice argument advocates for high-quality ECE for lowincome children as a means to "compensate for early disadvantages" (Siraj-Blatchford and Woodhead 2009, p. 1) and "level the playing field" between children from low- and high-income families (Yoshikawa et al. 2016).

I found the social justice argument in 19 news reports, a remarkably higher frequency than the children's right perspective. Some of the most illustrative quotes from experts in the field of ECE that apply for this category are: "ECE notably improves the school trajectories of the most vulnerable children, reducing repetition, drop-out, and the future exclusion of those youths that neither work nor study" (Estenssoro 2016, para. 5), 
"preschool and kindergarten impact studies show overwhelming positive results for the most disadvantaged children" (Bär 2016, para. 17), and "EC entails a window of opportunity for social policies: it is the moment to intervene and fight against inequities and inequalities" (Bauer 2016, para. 2).

Also, policy-makers supporting Law No 27.045 stated, "the norm is for helping the disadvantaged populations" (Desde este año and país 2015, para. 4) and, "it will diminish inequality" (Lupica as cited in Dillon 2014, para. 7). In an article titled "We are trying to close the gap", the then Ministry of Education claims: "The gap between children that attend 1 year to ECE and those who attended for 3 or 4 years is huge. To some extent, this explains the difficulties that children from low-income families face in primary school" (Sileoni 2014, para. 1).

In support of the ongoing project of lowering the mandatory starting age to 3 years, policy-makers and experts claim, "the true equality of opportunities does not start at elementary school" (Vidal as cited in "María Eugenia" 2016, para. 7), "ECE constitutes a clear commitment... to authentic equality of opportunities" (Riccardo as cited in Sued 2016, para. 4), "guarantees that children enter elementary school with higher equality of opportunities and reduces the chances of drop-out" (De Aróstegui 2016, para. 1) and, "benefits mostly the vulnerable populations who cannot afford child-care or kindergarten” (Zorzoli as cited in De Aróstegui 2016, para. 13).

The arguments I found for the National Plan for First Infancy were remarkably the same. For example, the current President explains that the construction of 4000 new CPIs aims "to avoid repetition and that children can succeed in secondary education" (Macri as cited in Rosemberg 2016, para. 3) and to ensure that "all Argentinean children have the same opportunities to progress" ("Mauricio Macri" 2016, para. 1).

In sum, the social argument emerged with more frequency than the children' rights perspective. It also appeared across the diverse editorials and in the voices of policymakers adhering to different political wings. Last, but hardly least, it is noteworthy that this line of argument heavily draws on citing research findings. However, these findings are extremely oversimplified when translated to the public: Evidence available regarding short and long term outcomes of ECE is notably less conclusive and more nuanced than the assertions I found in the news (Fuller 2007; Haskins and Barnett 2010; Stevens and English 2016). I will further reflect on this "oversimplification" issue in the concluding section.

\section{The human developmental argument}

As I describe in the introduction, EC experiences have a pivotal role in children's development. Hence, the first years of life are conceived as a "window of opportunity" to intervene. In this view, investing in ECE is promising as it provides a stimulating environment that can bolster children's cognitive, socio-emotional, and physical development (Neuman and Devercelli 2013). The arguments included for this case are similar to the ones from the previous section. They also stress that ECE "can ensure that children have a solid foundation for a productive future" (Center on the Developing Child 2007, p. 1). Yet, in contrast to the social justice argument, in this case social inequality is not specifically addressed. 
For this perspective, I found expert and policy-maker claims in 19 media outlets-the same frequency as for the social justice argument. Examples of claims evidencing the human development argument are: "[ECE] results in adults with... less susceptibility to health disease" (Sigman 2016, para. 2), and "it also helps enormously in the development of executive functions" (Sigman 2016, para. 4). "Decades ago we believed that school should start in kindergarten, at 5 years old. But neuroscience revealed that the first years of life are critical in the child's cognitive development" (Estenssoro 2016, para. 5). "The more years a child attends preschool, the better the primary school performance...Studies also indicate that ECE impacts other life dimensions, such as a professional career" (Furman as cited in Bär 2016, para. 18), and "mandatory education for 4-year-old children in the entire country will improve student's performance in primary and secondary education” (“Desde este año and país” 2015, para. 6).

The few parents' voices I encountered emerged in this line of arguments, explaining that the impact of out-of-home ECE on children's development was one of the reasons for enrolling their young children in preschools: "Our daughters developed earlier and better than kids of the same age due to the stimulus they received from the teachers [emphasis added]" (Bianchi as cited in Moscato 2016, para. 9).

In sum, the human development argument is also one of the most prominent arguments for policies that aim to universalize and establish preschool as mandatory. I found, once again, aligned claims across the four newspapers and between politically opposed policy-makers. Also for this line of arguments policy-makers and experts "filter" research findings (e.g., "neuroscience revealed," studies also indicate") to support their arguments for universal and mandatory ECE.

\section{The economic argument}

The fourth and last line of argument for ECE is the economic one. This case argues that the cost of investing in ECE outweighs future costs and that it results in higher returns than investments in later stages of life (Barnett and Masse 2007; Heckman 2006; Heckman et al. 2010). In three news reports reviewed, I identified the following assertions: "It is cheaper for the state to invest in ECE than to assume the cost later (Sigman 2016, para 2); EC is the best investment a government can make" ("Según Unicef” 2016, para. 3); "Experts guarantee that ECE investment is the most efficient" (Dillon 2014, para. 4). Clearly, of all of the arguments for universal and mandatory preschool, the economic argument is the one I identified least frequently.

\section{Arguments against early schooling}

The news reports discussing positions against out-of-home ECE were minimal. In fact, Law No 27.045 that made preschool mandatory for 4-year-old children "was approved in and without debate" ("El Congreso" 2014, para. 1). Likewise, the Chamber of Deputies approved the project of lowering the mandatory starting age to 3 years with "206 positives votes, five against and three abstentions" (Sued 2016, para. 3).

I only found three articles with straightforward objections to universal and mandatory preschool. However, the developmental period discussed in those articles was for children under the age of 3 , for whom mandatory policies have not (yet?) been proposed. The other arguments against emerged in eight news reports, but these were not 
objections to universal and mandatory preschool but rather "warnings" regarding the need to guarantee high-quality ECE services.

\section{The family choice argument}

Family choice-embedded in 3 articles-was one of the arguments against mandatory preschool. The following claim was made by a Deputy: "Mandatory preschool for age 3 neglects parental authority [patria potestad, as the legal Spanish term] (Carrió as cited in Sued 2016, para 3)". Parents' voices also emerged in this line of argument, stating that "each family has different needs" and that "the right time [for schooling] varies from case to case and has a lot to do with the familiar context rather than the child's development" (Moscato 2016, para. 4).

\section{The socioemotional development argument}

The second type of objection to ECE is the socioemotional development argument. As I explained above, in this case the developmental period discussed is for children under 3. I considered relevant to include this line of argument as it emerged in the news reports I analyzed although it is worth noting that it is not directly attached to the debate around universal and mandatory preschool policies.

The voices of professionals (e.g., psychologists and pediatricians) started out stressing that children are immature for the challenges ECE environments present, such as one adult per many children and long hours away from parents. "A 1-year-old child is not ready to be one among 15" (Moscato 2016, para. 7). "Currently, many children start school early, around 18 months, not even because of economic reasons. The argument is that the child will receive better stimulation than at home, making the child more intelligent. But not much is considered regarding emotional maturity. Schooling at such a young age entails psychological stress" (Vincaur 2016, para. 6).

\section{The high-quality warnings}

As I posited above, the largest number of objections do not directly disagree with universal and mandatory preschool but rather function as "warnings" about the need for "high-quality" settings.

For instance, regarding lowering the starting age to 3 years old, I found experts highlighting the need for funding and qualified educators: "Earlier schooling could be positive. But... it should entail a higher investment in infrastructure, teacher training and pedagogical resources" (De Aróstegui 2016, para. 14). "Far from being daycares centers, preschools must be learning environments. For this, the expansion of ECE needs to include a strong support for the principals and teachers" (Furman as cited in as cited in Bär 2016, para. 19).

Expectedly, most of the debate around the "quality" of ECE was focused on the topic of "alternative" ECE settings. Policy-makers and experts addressed the lack of pedagogical content, material, and human resources in the CPIs: "They are typical daycares and we have to turn them into real preschools. They do not work with curriculum, and in many cases, they lack certified teachers" (Ferraro as cited in Tuchin 2016, para. 11). "If the Plan [for First Infancy] is focused only on constructing [more centers] we assume the risk of lack of qualified human resources" (Repetto as cited in Tuchin 2016, para. 7). "We lack 
precision regarding short-term goals, funding per province, quality standards" (Waisgrais as cited in Tuchin 2016, para. 12).

To recapitulate, arguments against universal and mandatory preschool across the news reports were remarkably scarce. Only three articles presented straightforward objections to lowering the starting age of compulsory education, in the voices of families and one deputy. They stressed the right of families to decide about the education of their very young children. Remarkably, parents' views were only covered in one article. Yet, their voices still enacted arguments for and against out-of-home ECE. Last, but not least, most of the arguments against mandatory preschool were "warnings" related to the need to ensure both, access and quality.

\section{Discussion}

The media analysis confirms that ECE is currently a hot topic discussed in Argentina. In response to the question, what are the main topics newspapers cover? I found that, in addition to universal and mandatory preschool-on which I focused the analysis-technology and child development, paternal leave, child nutrition, child poverty, child abuse and maltreatment are recurrent covered topics as well. As I posited previously, this finding might be useful to inform further research studies on early childhood media debates. These diverse themes and the abounding news, clearly illustrate that EC is no longer a family-private issue, but has become a scientific, professional, and public matter (Bloch 1987).

That childhood has turned into a scientific and professional matter is also evidenced when answering the who says question. Policy-makers, scholars in the field of education, psychologists, neuroscientists, and pediatricians are the "actors [who] are granted "speech acts" or "claim making" in the public discourse" (Pyzomy-Levy 2016, p. 4). In contrast, there is absolutely no space available in the debate for teachers. Reflecting on this issue exceeds the scope of my study, but I cannot fail to mention that, probably, underpinning this striking finding there is a historical process of compartmentalization of educational theory and practice (Britzman 2003; Diker 2007). This fragmentation legitimated hierarchical power knowledge discourses and has left teachers, as knowers, "bereft of their capacity to intervene (in?) the world" (Britzman 2003, p. 29).

A likewise striking finding is that families are also "inaudible or silenced" (Juffermans and Van-Der Aa 2013, p. 114). Only one news report included parents' views and, interestingly, there was no consensus between them (i.e., I identified parents' voices for and against early schooling). In fact, in 2012, a national survey asked parents the reasons for not schooling their young children. The clear majority (78.7\%) argued they preferred not to do so. More precisely, $54.4 \%$ stated that they preferred their child to be raised by his or her mother or other kin and $24.3 \%$ claimed ECE was unnecessary for children under the age of 4 (Gerosa and Thourte $\mathrm{n} / \mathrm{d}$ ). Following the rise in ECE prominence, we need future research further examining parents' beliefs regarding mandatory ECE.

Linked to the issue of parents' voices, a striking finding is that the media coverage blurs the distinction between universal and mandatory preschool. This is particularly problematic because, for the Argentinean context, the mandatory reforms posed new obligations on the families not on the government: conceptually, universal encompasses the governmental obligation of ensuring educational supply for every child, while it does 
not entail for the families any obligation. Parents hold the right to choose whether their children will or will not attend preschool. On the contrary, mandatory requirements force families to send their children to school. It inhibits a parent's right to decide about the education of their children during their first years of life.

In 2006 the National Education Act No 26.026 established that, beyond mandatory kindergarten ( 5 years), the state has to ensure universal preschool for children of 4 years. This means that since 2006, the government was obliged to guaranteed the supply if families chose to enroll their 4-year-old children in public preschools. The passage of Law No 27.045, that lowered the mandatory starting age of education from 5 to 4 years, only entailed new obligations to the families and not the government. These markedly controversial issues were not evident in the newspaper coverage analysis. I wonder if parents and teachers would have more likely pointed them out had their voices been included in the debate.

On the other hand, regarding my third and last research question: why do they say what they say (i.e., arguments for and against expanding out-of-home ECE)? I found overwhelming support for universal and mandatory preschool. Policy-makers representing governments from divergent political parties exposed similar lines of argument for universal and mandatory preschool.

The Argentinean legislation is framed within the children's rights perspective and accordingly, universal preschool is supported as a children's right. Also, the social justice and child development arguments appeared repeatedly. In contrast, the economic argument was barely mentioned. Perhaps, its relative absence might be reflecting that the aims of ECE are also grounded in cultural and societal values, not just science. In this vein, narratives linked to children's rights and social justice seem to be better aligned with the Argentinean context than the cost-efficient rhetoric.

Additionally, the arguments for universal and mandatory preschool draw on research findings are uncritically filtered, decontextualized, and simplified, resulting in false assertions regarding the outcomes of ECE. While the strongest evidence regarding short- and long-term positive effects of ECE comes from high-quality interventions that proved to be cost-efficient investments (Barnett and Masse 2007; Heckman et al. 2010), the evidence on the impact of large-scale ECE programs is not as tidy and conclusive (Fuller 2007; Moss 2013; Schweinhart 2016; Stevens and English 2016). Even when standard levels of quality for ECE services are ensured, research indicates that children's gains fade out if they are not followed by later investments and high-quality elementary education as well (Currie 2006; Love and Brooks-Gunn 2010; Puma et al. 2012; Yoshikawa et al. 2016). As Schweinhart (2016) poignantly asserts: "Policy makers and the public widely know the idea that ECCE programs lead to long-term effects and return on investment; a few know that only high-quality ECCE programs result in such effects" [emphasis added] (p. 2). To put it simply: expecting that one or two additional years of attendance in ECE will reduce, for instance, the 50\% drop-out rate in Argentinean public high-schools (Narodowski 2016) is equal to, borrowing Brooks-Gunn's (2003) words, "believing in magic" (p. 3).

On the other hand, finding arguments against universal preschool, was like finding a needle in a haystack. Though very scant, those arguments did address the need for high-quality ECE. I found some experts and policy makers cautioning about the lack of 
infrastructure, qualified human resources, funding, clear goals and quality standards. Nevertheless, these issues were tangentially discussed. I argue they must be central to the debate of universal preschool: for decades now, scholars working in the field of ECE have been explaining the need of systemic approaches (Berlinski and Schady 2015; Britto et al. 2014; Kagan et al. 2012, 2016; Kagan and Cohen 1997). An ECE system is compound by ECE services, supported by a structure with clear governance and accountability entities, sustainable and efficient funding and financing streams, quality standards and a consistent teachers' professional development plan. Despite being sine qua non conditions to alleviate fragmentation and ensure high-quality services for all children (Kagan et al. 2012, 2016), they are overall ignored in the Argentinean ECE debate.

\section{Conclusion}

After conducting the newspaper coverage analysis, I conclude that Argentina needs to thoughtfully enrich the ongoing public debate around universal preschool. To enhance a more democratic debate, teachers' and families' voices should be included. It is also necessary to distinguish the concepts of universal versus mandatory preschool and their respective implications. Policy makers and even experts should draw more critically on the evidence available in the field. Their arguments regarding the benefits of ECE need to be more nuanced and contextualized.

In the current Argentinean context, none of the arguments for universal and mandatory preschool make sense: low-quality settings targeted to the neediest children neglect children's right to a happy childhood in a stimulating and responsive environment; rather than bolstering child-development and promoting social-justice, they deepen inequalities and socioeconomic segregation. Low-quality ECE will not lead to long-term positive outcomes, so it is probably that the benefits would not surpass the investments.

Of paramount importance, the debate on expanding access cannot be detached from the need to ensure quality. "The single most important lesson from developmental science and research on early childhood education and care is that quality matters" (Waldfogel 2006). Access and quality cannot advance through parallel paths. "If we want to see sustained improvements in children's development and learning, we need to increase the quality of-not just access to-preschool education" (Yoshikawa et al. 2016).

Given this information, it is concerning that ECE quality is not central in the ongoing debate and that systemic perspectives are meagerly addressed. Argentina will not overcome fragmentation and inequities in ECE by only expanding access; providing highquality ECE to all children would only be possible if Argentina strategically develops structural features, such as qualified human resources, sustainable funding streams, and quality standards. The abounding arguments for universal ECE would only be realized after overcoming the foundational fracture by strategically building a coherent and sustainable ECE system.

In short, instead of continuing to authorize controversial ECE laws in unison, Argentina needs to raise the level of the public debate. Universal and mandatory preschool issues in the media are extremely simplified. We are losing complexities, controversies and tensions that, for the sake of the future generations, need to be incorporated in the debate prior to ECE policy making. 


\section{Additional file}

Additional file 1. News Articles Database.

\section{Abbreviations}

EC: early childhood; ECE: early childhood education; CPIs: Centers of First Infancy; CeDIS: Centers for Child Development; NGOs: Non Governmental Organizations.

\section{Authors' contributions}

The author read and approved the final manuscript.

\section{Acknowledgements}

I thank Prof. Recchia, A. Rabadi-Raol and S. Khenkin for their thorough reading and constructive feedback of the manuscript.

\section{Competing interests}

The author declares no competing interests.

\section{Availability of data and materials}

The dataset supporting the conclusions of this article is included in the Additional file 1.

\section{Ethics approval and consent to participate}

Not applicable.

\section{Funding}

This research received no specific grant from any funding agency in the public, commercial, or not-for-profit sectors.

\section{Publisher's Note}

Springer Nature remains neutral with regard to jurisdictional claims in published maps and institutional affiliations.

Received: 20 September 2017 Accepted: 2 March 2018

Published online: 09 March 2018

\section{References}

Arakaki, A., Horenstein, J., Lichy, N., \& Trollu, M. T. (1986). Situación de los Jardines Maternales en Capital Federal, $1984-1985$. Buenos Aires: Ministerio de Educación y Justicia, Secretaría de Educación y Organización de los Estados Americanos. Araujo, M.C., López-Boo, F., \& Puyana, M. (2013). Overview of early childhood development services in Latin America and the Caribbean. Washington, DC: Inter-American Development Bank. https://publications.iadb.org/handle/11319/3617. Accessed 14 Sept 2017.

Bär, N. (2016, July 18). Pobreza: estudian la forma de mitigar el impacto en el cerebro. La Nación. http://www.lanacion. com.ar/1919511-pobreza-estudian-la-forma-de-mitigar-el-impacto-en-el-cerebro. Accessed 14 Sept 2017.

Barnett, W. S., \& Masse, L. N. (2007). Early childhood program design and economic returns: Comparative benefit-cost analysis of the Abecedarian program and policy implications. Economics of Education Review, 26, 113-125. https:// doi.org/10.1016/j.econedurev.2005.10.007.

Bassok, F., Finch, J. E., RaeHyuck, L., Reardon, S. F., \& Waldfogel, J. (2016). Socioeconomic gaps in early childhood experiences: 1998 to 2010. AERA Open, 2(3), 1-22. https://doi.org/10.1177/2332858416653924.

Bauer, F. (2016, November 17). Derechos desde la infancia. Clarín. https://www.clarin.com/opinion/Derechos-infancia_0_ SJaiTS5We.amp.html. Accessed 14 Sept 2017.

Berlinski, S. \& Schady, N. (2015). The early years. Child well-beign and the role of public policy. Interamerican Development Bank. https://publications.iadb.org/handle/11319/7259. Accessed 8 Jan 2018.

Bloch, M. N. (1987). Becoming scientific and professional: An historical perspective on the aims and effects of early education. In T. S. Popkewitz (Ed.), The formation of the school subjects (pp. 25-62). New York: Falmer Press.

Brennan, D. (2007). The ABC of child care politics. Australian Journal of Social Issues, 42(2), 213-222. https://doi. org/10.1002/j.1839-4655.2007.tb00050.x.

Britto, P. R., Yoshikawa, H., van Ravens, J., Ponguta, L. A., Reyes, M., Oh, S., et al. (2014). Strengthening systems for integrated early childhood development services: A cross-national analysis of governance. Annals of the New York Academy of Sciences, 1308(1), 245-255.

Britzman, D. P. (2003). Practice makes practice. Albany: Suny Press.

Brooks-Gunn, J. (2003). Do you believe in magic? What we can expect from early childhood intervention programs. Social Policy Report, 17(1), 1-14

Brooks-Gunn, J., \& Duncan, G. J. (1997). The effects of poverty on children. Future of Children, 7(2), 55-71.

Burgos, N., \& Silva, M. D. (2018). Los maestros del nivel inicial, entre la cualificación y la proletarización. Reflexiones sobre debates que continúan vigentes. RELADEl, Revista Latinoamericana de Educación Infantil, 1, 27-38. 
Cahan, E. D. (1989). Past caring: A history of U.S preschool care and education for the poor, 1820-1965. New York: National Center for Children in Poverty.

Center on the Developing Child. (2007). Early childhood program effectiveness. Inbrief series. http://developingchild.harvard.edu/resources/inbrief-early-childhood-program-effectiveness/. Accessed 14 Sept 2017.

Couse, L. J., \& Recchia, S. L. (2016). Introduction. In L. J. Couse \& S. L. Recchia (Eds.), Handbook of early childhood teacher education (pp. XV-XVII). New York: Routdledge.

Currie, J. (2006). Who's minding the kids? In J. Currie (Ed.), Invisible safety net (pp. 113-193). Princeton: Princeton University Press.

De Aróstegui, F. J. (2016, August 30). Sala de 3 años obligatoria, la meta educativa que avanza en el Congreso. La Nación. http://www.lanacion.com.ar/1932900-sala-de-3-anos-obligatoria-la-meta-educativa-que-avanza-en-el-congreso. Accessed 14 Sept 2017.

Desde este año, será obligatoria la sala de 4 años en todo el país (2015, January 7). La Nación. http://www.lanacion.com. ar/1758171-desde-este-ano-sera-obligatoria-la-sala-de-4-anos-en-todo-el-pais. Accessed 14 Sept 2017.

Diker, G. (2001). Organización y perspectiva de la educación inicial en Iberoamérica, principales tendencias. Organization of Iberoamerican States. http://www.oei.es/historico/observatorio2/tendencias.htm. Accessed 14 Sept 2017.

Diker, G. (2007). Autoridad, poder y saber en el campo de la Pedagogía. Revista Colombiana de Educación, 52, 150-171.

Dillon, A. (2014, September 9). Anuncio official: Será obligatoria la sala de 4 del jardín de infant. Clarín. https://www.clarin. com/sociedad/Anuncio-oficial-obligatoria-jardin-infantes_0_S12lll95vmg.html. Accessed 14 Sept 2017.

Diputados aprobó la obligatoriedad de salas de 3. (2016, November 17). Diario Popular. https://www.diariopopular.com. ar/politica/diputados-aprobo-la-obligatoriedad-salas-3-n272709. Accessed 14 Sept 2017.

Duras críticas a la ley que habilita maestros sin título en Provincia. (2016, September 17). Clarín. https://www.clarin.com/ sociedad/Polemica-maestros-titulo-Provincia_0_H1VZYYF5VVXe.html. Accessed 14 Sept 2017.

El Congreso incluyó a la sala de 4 años. (2014, December 4). La Nación. http://www.lanacion.com.ar/1749252-el-congreso-incluyo-a-la-sala-de-cuatro-anos. Accessed 14 Sept 2017.

El Gobierno construirá 2000 salas para 4 años. (2014, September 8). Página 12. https://www.pagina12.com.ar/diario/ultimas/20-254824-2014-09-08.html. Accessed 5 Mar 2018.

Estenssoro, M.E. (2016, February 14). La Argentina, a contramano en la educación inicial. La Nación. http://www.lanacion. com.ar/1663938-la-argentina-a-contramano-en-la-educacion-inicial. Accessed 14 Sept 2017.

Farrell, A., Kagan, S. L., \& Tisdall, E. K. M. (2016). Early childhood research: An expanding field. In A. Farrell, S. L. Kagan, \& E. K. M. Tisdall (Eds.), The sage handbook of early childhood research (pp. 1-11). London: SAGE Publications.

Fuller, B. (2007). Standardized childhood. The political and cultural struggle over early childhood education. California: Stanford University Press.

Gerosa, S., \&Thourte, M. (n/d). Encuesta sobre condiciones de vida de niñez y adolescencia. Ministerio de Desarrollo Social de la Nación and UNICEF. https://www.unicef.org/argentina/spanish/MICS_CierreJulio2013_BAJAWEB.pdf. Accessed 14 Sept 2017.

Haskins, R., \& Barnett, W. S. (2010). New directions for America's early childhood policies. In R. Haskins \& W. S. Barnett (Eds.), Investing in young children. New directions in federal preschool and early childhood policy (pp. 1-27). London: Center on Children and Families at Brookings \& National Institute for Early Education Research.

Heckman, J. (2006). Skill formation and the economics of investing in disadvantaged children. Science, 312, 1900-1902. https://doi.org/10.1126/science.1128898.

Heckman, J., Moon, S., Pinto, R., Savelyev, P., \& Yavitz, A. (2010). The rate of return to the High Scope Perry Preschool Program. Journal of Public Economics, 94, 114-128.

Hodgertts, D., \& Chamberlain, K. (2014). Analysing news media. In U. Flick (Ed.), The SAGE handbook of qualitative data analysis (pp. 390-393). London: SAGE.

Itzcovich, G. (2010). Tendencias recientes del nivel inicial: un análisis estadístico de la situación argentina. Buenos Aires: OEl y UNICEF Argentina.

Johnson, A. D., \& Brooks-Gunn, J. (2012). Child care and early education for low-income families: Choices and consequences. In W. Maholmes \& R. King (Eds.), The Oxford handbook of poverty \& child development (pp. 354-371). New York: Oxford University Press.

Juffermans, K., \& Van-Der Aa, J. (2013). Introduction to the special issue: Analyzing voice in educational discourses. Anthropology \& Education Quarterly, 44(2), 112-123. https://doi.org/10.1111/aeq.12010,

Kagan, S.L. (2009). American early childhood education: Preventing or perpetuating inequity? New York, NY: Teachers College, Campaign for Educational Equity. https://pdfs.semanticscholar.org/1efa/6a15e1 eb04b3e05ecbd2be4884fca8 b9f96.pdf Accessed 14 Sept 2017.

Kagan, S. L., Araujo, M. C., Jaimovich, A., \& Cruz Aguayo, Y. (2016). Understanding systems theory and thinking: Early childhood education in Latin America and the Caribbean. In A. Farrell, S. L. Kagan, \& E. K. M. Tisdall (Eds.), The SAGE handbook of early childhood research (pp. 163-184). London: SAGE Publications.

Kagan, S. L., \& Cohen, N. (1997). Not by chance: Creating an early care and education system for America's children (abridged version). New Haven: Yale University Bush Center in Child Development and Social Policy.

Kagan, S. L., Tarrant, K., \& Kauerz, K. (2012). Planning an early childhood system. In S. L. Kagan \& K. Kauerz (Eds.), Early childhood systems: Transforming early learning (pp. 137-154). New York: Teachers College Press.

Kantor, D., \& Kaufmann, V. (2008). Prácticas y experiencias educativas en jardines comunitarios. Buenos Aires: Fundación C\&A.

López, N. (coord.) (2012). La situación de la primera infancia en Argentina. A dos décadas de la ratificación de la Convención de los Derechos del Niño. Córdiba, Argentina: Fundación Arcor. http://www.sipi.siteal.iipe.unesco.org/sites/default/ files/sipi_publicacion/informe_situacion_infancia_completo.pdf. Accessed 21 Feb 2018.

Love, J. M., \& Brooks-Gunn, J. (2010). Getting the most out of Early Head Start: What has been accomplished and what needs to be done. In R. Haskins \& W. S. Barnett (Eds.), Investing in young children. New directions in federal preschool and early childhood policy (pp. 29-37). London: Center on Children and Families at Brookings \& National Institute for Early Education Research.

Malajovich, A. (2010). "Deudas educativas con la primera infancia", en Revista Voces en el Fénix, Argentina, (3), 34-37. http:// www.vocesenelfenix.com/sites/default/files/pdf/8malajovich_3_0.pdf. Accessed 21 Feb 2018. 
María Eugenia Vidal volvió a mostrarse junto a Facundo Manes en territorio bonaerense. (2016, October 18). La Nación. http://www.lanacion.com.ar/1948170-maria-eugenia-vidal-volvio-a-mostrarse-junto-a-facundo-manes-en-territorio-bonaerense. Accessed 14 Sept 2017.

Matheson, D. (2005). Media discourses. New York: Open University Press.

Mauricio Macri prometió que en cuatro años habrá 4000 Centros de Primera Infancia. (2016, April 11). La Nación. http:// www.lanacion.com.ar/1888302-mauricio-macri-prometio-que-en-cuatro-anos-habra-4000-centros-de-primerainfancia. Accessed 14 Sept 2017.

Martin, San, de Duprat, H., Malajovich, A., \& Wolodarsky Estrín, S. (1977). Hacia el jardín maternal, dilemas y propuestas. Buenos Aires: Ediciones Búsqueda.

Morduchowicz, A. (Ed.). (1999). La educación privada en la Argentina: Historia, regulaciones y asignación de recursos públicos. Buenos Aires: Mimeo.

Moscato, L. (2016, April 9). ¿Todavía no va al jardín? La Nación. http://www.lanacion.com.ar/1887761-todavia-no-va-aljardin. Accessed 14 Sept 2017.

Moss, P. (2013). Beyond the investment narrative. Contemporary Issues in Early Childhood, 14(4), 370-372. https://doi. org/10.2304/ciec.2013.14.4.370.

Naeyc. (2009). Developmentally appropriate practice in early childhood programs serving children from birth through age 8. National Association for the Education of Young Children. Retrieved from https://www.naeyc.org/resources/ position-statements/. Accessed 18 Feb 2018.

Narodowski, M. (2016). El abandono en la escuela media Argentina. Buenos Aires: Instituto de Investigación y Educación Económica. http://ie.org.ar/2015/educacion/. Accessed 14 Sept 2017.

Narodowski, M., \& Andrada, M. (2001). The privatization of education in Argentina. Journal of Education Policy, 16(6), 585-595.

Narodowski, M., Gottau, V., \& Moschetti, M. (2016). Quasi-State monopoly of the education system and socio-economic segregation in Argentina. Policy Futures in Education, 14(6), 687-700. https://doi.org/10.1177/1478210316645016.

Narodowski, M., \& Moschetti, M. (2015). Why does private school enrollment grow? Evidence from Argentina. Cogent Education, 2(1), 1-16. https://doi.org/10.1080/2331186X.2015.1077604.

Narodowski, M., \& Snaider, C. (2015). ¿ Neoliberalismo? El crecimiento de la educación privada en Argentina y Uruguay. Revista Sudamericana de Educación, Universidad y Sociedad, 4, 49-74.

Narodowski, M. \& Snaider, C. (2017). ¿Bebés en las escuelas? Infancias hiperescolarizadas en una cultura prefigurativa. Revista Latinoamericana de Ciencias Sociales, Niñez y Juventud, 15(1), 45-57. http://revistaumanizales.cinde.org.co/ index.php/Revista-Latinoamericana/article/view/2947. Accesses 14 Sept 2017.

National Agency of Information and Statistics in Education (2015). Anuario Estadístico Educativo 2015. http://portales. educacion.gov.ar/diniece/2014/05/24/anuarios-estadisticos/. Accessed 5 Mar 2018.

National Institute of Statistics and Census. (2012). Censo nacional de población, hogares y viviendas 2010. Censo del Bicentenario. Resultados definitivos. Serie B No. 2. Tomo 1. Buenos Aires: Instituto Nacional de Estadística y Censos, http://www.indec.gov.ar/nivel3_default.asp?id_tema_1=2\&id_tema_2=41. Accessed 14 Sept 2017.

National Scientific Council on the Developing Child. (2007). The timing and quality of early experiences combine to shape brain architecture: Working Paper No. 5. Center on the Developing Child at Harvard University. http://www. developingchild.net. Accessed 14 Sept 2017.

Neuman, M.J., \& Devercelli, A.E. (2013). What matters most for early childhood development: A framework paper. Systems Approach for Better Education Results (SABER) Working Paper, No. 5. Washington, DC: The World Bank. https:// openknowledge.worldbank.org/bitstream/handle/10986/20174/901830NWPOno5000Box385307B00PUBLIC0. pdf? sequence $=1$ \&isAllowed=y. Accessed 14 Sept 2017.

New, R. (2016). 21st century early childhood teacher education. New frames for a shifting landscape. In L. J. Copuse \& S. L. Recchia (Eds.), Handbook of early childhood teacher education (pp. 3-19). New York: Routledge.

Ponce, R. (2006). Los debates de la educación en la Argentina. Persistencias, transformaciones y resignificaciones a lo largo de la historia. In A. Malajovich (Ed.), Experiencias y reflexiones sobre la educación inicial: una mirada latinoamericana (pp. 19-102). Buenos Aires: Siglo XXI Editores.

Puma, M., Bell, S., Cook, R., Heid, C., Broene, P., Jenkins, F. \& Downer, J. (2012). Third grade follow-up to the head start impact study: Final report. administration for children \& families. US Department of Health and Human Services. https://www.acf.hhs.gov/sites/default/files/opre/head_start_report.pdf. Accessed 14 Sept 2017.

Pyzomy-Levy, O. (2016). Compare globally, interpret locally: International assessments and news media in Israel. Columbia University Academic Commons. https://academiccommons.columbia.edu/catalog/ac:198298. Accessed 14 Sept 2017.

Repetto, F., Langou, G. D., \& Aulicino, C. (2012). Cuidado Infantil en la Ciudad Autónoma de Buenoa Aires ¿La disyuntiva entre pañales y pedagogía?. Buenos Aires: CIPPEC.

Redondo, P. (2012). Políticas en debate: La atención educativa de la primera infancia en la Argentina. Propuesta Educativa, 21(37), 6-16.

Rosemberg, J. (2016, May 19). El BID confirmó un préstamo de US\$ 300 millones para políticas sociales de primera infancia y educación. La Nación. http://www.lanacion.com.ar/1900345-el-bid-confirmo-un-prestamo-de-us-300-millones-para-politicas-sociales-de-primera-infancia-y-educacion. Accessed 14 Sept 2017.

Schweinhart, L. J. (2016). Use of early childhood longitudinal studies by policy makers. International Journal of Child Care and Educational Policy, 10(6), 1-10.

Schweinhart, L., Montie, J., Xiang, Z., Barnett, W. S., Belfield, C. R., \& Nores, M. (2005). Lifetime effects: The High/Scope Perry Preschool study through age 40. Ypsilanti: High/Scope Press. https://doi.org/10.1186/s40723-016-0023-5.

Según Unicef, la primera infancia es la mejor inversión de un gobierno. (2016, December 13). La Nación. http://www. lanacion.com.ar/1966668-segun-unicef-la-primera-infancia-es-la-mejor-inversion-de-un-gobierno. Accessed 14 Sept 2017.

Shonkoff, J.P., \& Phillips, D. (2000). From neurons to neighborhoods: The science of early childhood development. Committee on Integrating the Science of Early Childhood Development. Washington, DC: National Academy Press. https:// 
www.nap.edu/catalog/9824/from-neurons-to-neighborhoods-the-science-of-early-childhood-development. Accessed 14 Sept 2017.

Sigman, M. (2016, April 1). El desarrollo temprano, un derecho y una buena inversión. La Nación. http://www.lanacion. com.ar/1887783-el-desarrollo-temprano-un-derecho-y-una-buena-inversion. Accessed 14 Sept 2017.

Sileoni, A. (2014, Septemeber 5). Estamos tratando de cerrar la brecha. Página 12. https://www.pagina12.com.ar/diario/ elpais/1-254590-2014-09-05.html. Accessed 14 Sept 2017.

Siraj-Blatchford, I., \& Woodhead, M. (2009). Effective early childhood programs. Early Childhood in Focus 4. UK: The Open University. http://oro.open.ac.uk/19300/1/ECiF4-final_as_published_-English.pdf. Accessed 14 Sept 2017.

Sigillo, A. E., \& Sicafuse, L. L. (2015). The Influence of media and community sentiment on policy decision-making. In M. Miller, J. Blumenthal, \& J. Chamberlain (Eds.), Handbook of community sentiment. New York: Springer.

Snaider, C. (2014). El Nivel Inicial en la Ciudad de Buenos Aires. Lógicas que ordenan ofertas crecientes y diversas. Tesis de Maestría, Universidad Torcuato Di Tella.

Snaider, C. (2016). La universalización del nivel incial. Logros, limitaciones y desafíos a partir de la evidencia de la Ciudad de Buenos Aires. Buenos Aires: Instituto de Investigación y Educación Económica. http://ie.org.ar/2015/educacion/. Accessed 14 Sept 2017.

Soroka, S., Lawlor, A., Farnsworth, S., \& Young, L. (2012). Mass media and policymaking. In W. Xum, M. Ramesh, M. Howlett, S. Fritzen, \& E. Araral (Eds.), Routledge handbook of the policy process (pp. 204-214). New York: Routledge.

Sverdlick, I., Pagano, A., \& Borzese, C. (2007). La situación de la primera infancia en la provincia de Buenos Aires. La acción de las organizaciones y movimientos sociales. Buenos Aires: Unipe.

Stevens, K.B., \& English, E. (2016). Does Pre-KWork? The research on ten early childhood programs and what it tells us. American Enterprise Institute. http://www.aei.org/publication/does-pre-k-work-the-research-on-ten-early-childhoodprograms-and-what-it-tells-us/. Accessed 14 Sept 2017.

Sued, G. (2016, November 17). Respaldo legislativo a la sala de 3 años. La Nación. http://www.lanacion.com.ar/1956996respaldo-legislativo-a-la-sala-de-3-anos. Accessed 14 Sept 2017.

Terigi, F. (2012). La escolarización como política hacia la primera infancia. In UNICEF (Ed.), Crecer juntos para la primera infancia. Encuentro regional de políticas integrales 2011 (pp. 125-129). Buenos Aires: UNICEF.

Tuchin, F. (2016, July 7). Advertencias y críticas al Plan Nacional de Primera Infancia. La Nación. http://www.lanacion.com. ar/1916051-advertencias-y-criticas-al-plan-nacional-de-primera-infancia. Accessed 14 Sept 2017.

Unesco. (2016). Educación para todos. Revisiones nacionales de la EPT al 2015. Argentina. http://unesdoc.unesco.org/ images/0023/002303/2303075.pdf. Accessed 14 Sept 2017.

Unicef, Flaso \& Cippec (n/d). Análisis de los Centros de Primera Infancia. Principales resultados. Informe preliminar. http:// www.cippec.org/publicaciones. Accessed 14 Sept 2017.

UNICEF \& UNSAM. (2011). Servicio de atención a niños y niñas de 45 días a 36 meses. Buenos Aires: UNICEF.

Vincaur, N. (2016, Abril 9). La madurez afectiva, clave durante los procesos de escolarización. La Nación. http://www.lanacion.com.ar/1887785-la-madurez-afectiva-clave-durante-los-procesos-de-escolarizacion. Accessed 14 Sept 2017.

Vior, S., \& Rodríguez, S. (2012). La privatización de la educación argentina: Un largo proceso de expansión y naturalización. Pro-Posiçoes, 23(68), 91-104.

Waldfogel, J. (2006). Early childhood policy: A comparative perspective. In D. Phillips \& K. McCartney (Eds.), Blackwell handbook of early childhood development (pp. 576-594). Malden: Blackwell.

Yoshikawa, H., Weiland, C., \& Brooks-Gunn, J. (2016). When does preschool matter? The Future of Children, 16(2), 21-35. http://www.jstor.org/stable/43940579. Accessed 14 Sept 2017.

\section{Submit your manuscript to a SpringerOpen ${ }^{\circ}$ journal and benefit from:}

- Convenient online submission

Rigorous peer review

Open access: articles freely available online

- High visibility within the field

- Retaining the copyright to your article

Submit your next manuscript at $\boldsymbol{\nabla}$ springeropen.com 